\title{
PERSEPSI MAHASISWA PGSD DALAM PEMBELAJARAN MATA KULIAH PENDIDIKAN KARAKTER MELALUI JURNAL BELAJAR
}

\section{Rifda Mardian Arif ${ }^{1}$, Rahidatul Laila Agustina ${ }^{2}$, Yudha Adrian ${ }^{3}$}

1. Program Studi Pendidikan Guru Sekolah Dasar STKIP PGRI Banjarmasin E-mail: dianarif2289@gmail.com,

2. Program Studi Pendidikan Guru Sekolah Dasar STKIP PGRI Banjarmasin E-mail: androiid337@gmail.com

3. Program Studi Pendidikan Guru Sekolah Dasar STKIP PGRI Banjarmasin E-mail: rahidatul.agustina@gmail.com

\begin{abstract}
ABSTRAK
Tujuan penelitian ini adalah untuk mengaji pengetahuan, persepsi dan persepsi mahasiswa dalam mata kuliah pendidikan karakter melalui jurnal belajar yang ditulis oleh setiap mahasiswa PGSD di setiap akhir perkuliahan. Jurnal belajar yang ditulis oleh mahasiswa PGSD berisikan deskripsi mengenai kemenarikan dan kendala atau hal-hal apa saja yang tidak dipahami dalam materi yang disampaikan di setiap perkuliahan. Penelitian ini menggunakan pendekatan kualitatif. Peneliti dalam penelitian ini bertindak sebagai pengumpul data. Status kehadirannya adalah sebagai pengamat terhadap informan atau pengamat penuh. Dengan kata lain, instrumen kunci adalah peneliti itu sendiri.

Hasil penelitian menunjukkan bahwa jurnal belajar dimanfaatkan sebagai alat bantu untuk mengetahui persepsi mahasiswa terkait materi yang telah diajarkan. Persepsi tersebut bermacam-macam tergantung pendapat dari responden tersebut. Pada dasarnya jurnal belajar memaparkan pemahaman responden terhadap materi yang masih membekas dalam ingatannya. Selain itu, jurnal belajar dapat digunakan untuk mengamati perkembangan kemampuan responden dalam menangkap materi yang diajarkan. Hasil belajar yang terlaksana pada setiap pertemuan dapat dilihat oleh dosen pengampu mata kuliah.
\end{abstract}

Kata kunci : Persepsi, Pendidikan Karakter, Jurnal Belajar 


\section{PENDAHULUAN}

Pendidikan karakter ditempatkan sebagai landasan untuk mewujudkan visi pembangunan nasional, yaitu terwujudnya masyarakat yang berakhlak mulia, bermoral, beretika, berbudaya, dan beradab berdasarkan falsafah pancasila. Hal ini sekaligus menjadi upaya untuk mendukung perwujudan cita-cita sebagaimana diamanatkan dalam pancasila dan pembukaan Undang-Undang Dasar 1945.

Pendidikan karakter dimaknai sebagai pendidikan nilai, pendidikan moral, pendidikan budi pekerti, pendidikan watak, dan pendidikan akhlak dengan tujuan untuk mengembangkan kemampuan peserta didik dalam memberikan keputusan baik-buruk, memelihara sesuatu yang baik, dan mewujudkan kebaikan di kehidupan sehari-hari. Pendidikan karakter sebagai konsep pendidikan melibatkan aspek pengetahuan (cognitive), perasaan (feeling), serta tindakan (action). Dengan kata lain dalam pendidikan karakter, sistem penanaman nilai-nilai kebaikan kepada warga sekolah atau kampus tidak hanya berpusat pada aspek pengetahuan saja, melainkan juga pada aspek kesadaran atau kemauan, serta tindakan untuk melaksanakan nilai-nilai tersebut sehingga menjadi manusia yang seutuhnya.

Program Studi PGSD merupakan wadah untuk mencetak calon-calon guru SD yang berkualitas. Guru SD, merupakan peletak dasar pendidikan pertama bagi anak-anak bangsa. Guru yang berkualitas akan menghasilkan peserta didik yang berkualitas pula. Tidak hanya dari sisi kognitif, afektif dan psikomotor juga sangat dikembangkan di jurusan ini. Beberapa indikator yang dikembangkan dalam pembelajaran pendidikan budaya dan karakter bangsa adalah religius, jujur, teloransi, disiplin, kerja keras, disiplin, kritis, kreatif, mandiri, demokratis, rasa ingin tahu, semangat kebangsaan, cinta tanah air, menghargai prestasi, komunikatif, cinta damai, gemar membaca, peduli sosial, tanggung jawab. Semua indikator tersebut idealnya dapat diterapkan pada semua mata kuliah yang ada di Jurusan PGSD.

Kualitas program studi pendidikan guru sekolah dasar ditandai oleh kualitas lulusan LPTK, artinya kualitas lulusan LPTK merupakan cermin dari kualitas LPTK itu sendiri. Setiap pendidik sebagai lulusan LPTK dituntut memiliki kemampuan dalam membina karakter peserta didik. Jadi, pembinaan karakter mahasiswa calon tenaga pendidik merupakan bagian yang tidak terpisahkan dari pendidikan tenaga pendidik oleh LPTK. Oleh karena itu, Program Studi Pendidikan Guru Sekolah Dasar mengusung visi menjadi LPTK penghasil dan pengembang tenaga kependidikan yang unggul, profesional dan berkarakter yang direalisasikan melalui implementasi nilai-nilai karakter dalam pembelajaran di kelas

Slogan berkarakter belum dapat dilaksanakan dengan optimal. Realita di lapangan masih banyak ditemukan penyimpangan-penyimpangan perilaku sebagai bukti adanya kesenjangan antara indikator pencapaian nilai-nilai berkarakter dengan pelaksanaan praktis di lapangan. Dengan demikian penelitian ini dilakukan untuk mengaji pengetahuan, persepsi dan persepsi mahasiswa dalam mata kuliah pendidikan karakter melalui jurnal belajar yang ditulis oleh setiap mahasiswa PGSD di setiap akhir perkuliahan. Jurnal belajar yang ditulis oleh mahasiswa PGSD berisikan deskripsi mengenai kemenarikan dan kendala atau hal-hal apa saja yang tidak dipahami dalam materi yang disampaikan di setiap 
perkuliahan. Akhirnya, penelitian ini diharapkan dapat menjadi salah satu acuan dalam perencanaan, pelaksanaan, dan evaluasi dalam implementasi nilai-nilai karakter pada pembelajaran secara umum, maupun pembelajaran pendidikan karakter secara khusus dengan bercermin pada persepsi-persepsi mahasiswa.

\section{METODE PENELITIAN}

Penelitian ini merupakan jenis penelitian kualitatif, dengan objek penelitian bersifat alami, data penelitian berupa kata-kata, kalimat-kalimat, paragraf, tindakan atau kegiatan seseorang. Data berbentuk deskriptif dan perolehan data bersifat induktif berawal dari kopseptualisasi, katagorisasi, dan deskripsi yang dikembangkan atas dasar kejadian yang diperoleh melalui penelitian di lapangan. Peneliti dalam penelitian ini bertindak sebagai pengumpul data. Status kehadirannya adalah sebagai pengamat terhadap informan atau pengamat penuh. Dengan kata lain, instrumen kunci adalah peneliti itu sendiri.

Sumber data dalam penelitian ini adalah mahasiswa STKIP PGRI Banjarmasin Program Studi Pendidikan Sekolah Dasar (PGSD) semester 1. Jenis data yang diambil adalah hasil dokumentasi, wawancara, dan observasi. Penentuan sampel pada penelitian ini dengan teknik purposive sampling. Hal ini dilakukan karena terdapat pertimbangan tertentu dalam pengumpulan data.

Proses tahapan pada penelitian ini mengacu pada langkah-langkah penelitian kualitatif mengadaptasi dari Moleong (2005) meliputi: (1) tahap pra lapangan, terdiri atas kegiatan menyusun rancangan penelitian, memilih lapangan penelitian, mengurus perijinan, menjajaki dan menilai lapangan penelitian, memilih informan, dan menyiapkan perlengkapan penelitian; (2) tahap pengerjaan lapangan terdiri atas memahami latar penelitian dan persiapan diri, memasuki lapangan, berperan serta sambil mengambil data; dan (3) tahap analisis data.

Pengumpulan data penelitian ini menggunakan teknik: (1) wawancara mendalam, (2) observasi, dan (3) dokumentasi (Cresswell, 2005). Untuk perencanaan prosedur kerja yang akan dilakukan terhadap responden adalah sebagai berikut; (a) Menetapkan jumlah sampel responden, (b) Melakukan wawancara tentang identitas dan deskripsi diri responden, persepsi, serta hubungan yang terjalin antara sesama mahasiswa, (c) Membuat catatan hasil wawancara (field note). (d) Mengolah hasil wawancara responden dalam bentuk narasi, (e) Memaparkan hasil akhir wawancara yang berisi pemaparan hasil dalam bentuk diagram pada saat sebelum serta sesudah penelitian dilaksanakan agar diperoleh kerangka pola pikir persepsi diantara keduanya, (f) Membuat dokumentasi penelitian berupa foto kegiatan penelitian

Analisis data dilakukan selama dan setelah pengumpulan data, dengan teknik analisis tema. Langkah-langkah di dalam analisis data kualitatif. Pengujian keabsahan data menggunakan teknik triangulasi sumber dan teori. Uji kredibilitas dilakukan melalui diskusi tentang apa yang sedang diteliti dengan teman sejawat atau dosen yang memiliki kesamaan bidang dengan peneliti (dalam hal ini adalah bidang pendidikan).

\section{HASIL DAN KAJIAN}




\section{Hasil Penelitian}

Subjek pada penelitian ini adalah mahasiswa angkatan pertama prodi PGSD atau mahasiswa tingkat awal semester I yang baru menempuh pendidikan strata 1 di STKIP PGRI Prodi PGSD. Pemaparan data hasil penelitian didasarkan pada hasil wawancara dengan sampel yang telah ditentukan berdasarkan purposive sampling. Pengambilan subjek dilakukan dengan tujuan tertentu agar saat wawancara didapatkan data yang komprehensif.

Data yang dipaparkan berkenaan dengan persepsi responden terhadap jurnal belajar. Selain itu, kebermanfaatan jurnal belajar dalam proses dan pasca proses pembelajaran. Kendala yang dihadapi responden selama menulis jurnal belajar pada setiap kali pertemuan. Terakhir, pencapaian proses pembelajaran yang ditempuh oleh responden selama mengkuti mata kuliah pendidikan karakter. Ada 3 responden yang diteliti dalam penelitian ini, yang pertama responden $\mathrm{DH}$, kedua DF dan ketiga HA. Alasan pemilihan DH, DF dan HA dalam penelitan ini adalah karena menurut peneliti mereka bertiga dapat mewakili kemampuan intelektual di kelas tersebut. Baik kategori dengan intelektual tinggi, intelektual sedang maupun intelektual rendah.

Berdasarkan hasil wawancara dengan subjek penelitian didapatkan hasil penelitian berupa data dari wawancara secara langsung maupun yang melalui angket serta penugasan melalui jurnal belajar. Sebagian besar subjek berpendapat bahwa pendidikan karakter sangat penting diberikan bahkan sedari dini kepada siswa baik dalam pembelajaran disekolah maupun di lingkungan keluarga. Subjek lain ada juga yang berpendapat bahwa pendidikan karakter hanya bisa terbentuk melalui lingkungan keluarga, bukan pada lingkungan sekolah bahkan pada lingkup kegiatan belajar mengajar di dalam kelas.

Dari data yang diperoleh subjek menunjukkan bahwa pemahaman responden mahasiswa tingkat awal angkatan ke-1 Prodi PGSD atas makna berkarakter kuat dan cerdas sangat beragam. Kebanyakan dari mereka sudah mengarah pada satu pemahaman, yakni bahwa sebagai pendidikan karakter dipahami sebagai kriteria ideal yang harus melekat dalam kepribadian seorang pendidik dan mereka sebagai calon pendidik, yang diharapkan dapat dimiliki oleh mahasiswa STKIP PGRI Prodi PGSD khususnya sebagai calon guru, yang dapat memberikan kekhasan pada dirinya, sehingga dapat dibedakan dengan mahasiswa dari prodi lain. Namun sebagian besar para responden belum sepenuhnya mencerminkan sikap yang berkarakter kuat dan cerdas. Seperti pengakuan salah seorang responden yang mengaku sekedar mengetahui definisi pendidikan karakter saja, namun belum dapat mengetahui praksis apa yang harus dilakukan sebagai konsekuensi aplikatifnya dalam pembelajaran di dalam kelas.

Responden DF dengan kategori intelektual sedang berpendapat bahwa jurnal belajar merupakan sesuuatu yang kita fahami dan tidak fahami dalam proses pembelajaran Hal-hal yang ditulis oleh responden dalam dalam jurnal belajar merupakan hal-hal yang dianggap menarik oleh responden selama pembelajaran berlangsung. Dengan kata lain, responden diperbolehkan mendeskripsikan materi-materi yang telah mereka tangkap selama proses pembelajaran dari pertemuan pertama sampai pertemuan terakhir dengan menggunakan bahasa yang lebih mudah mereka fahami. Jurnal belajar merupakan alat yang digunakan untuk mendeskripsikan hal-hal yang dianggap penting oleh 
responden. Jurnal belajar digunakan sebagai sarana untuk menuangkan hal-hal yang dirasa penting dan dipahami oleh responden. Dengan kata lain, pada penelitian ini jurnal belajar dijadikan sebagai instrumen pendukung dalam mengumpulkan data.

Penulisan jurnal belajar memberikan dampak positif bagi subjek penelitian. Manfaat tersebut tidak secara eksplisit dapat dilihat oleh subjek penelitian, akan tetapi secara implisit jurnal belajar sangat bermanfaat bagi dosen pengampu mata kuliah pendidikan karakter. Dosen dapat melihat progress mahasiswanya dalam belajar. Dosen dapat memantau kelebihan dan kekurangan dari proses pembelajaran berdasarkan perpektif mahasiswa. Dengan kata lain, jurnal belajar dapat mewakili kebermaknaan proses pembelajaran menurut sudut pandang mahasiswa. Sehingga dosen dapat mengetahui apa saja kekurangankekurangan yang didapat selama proses pembelajaran berlangsung. Jurnal belajar juga dapat dikatakan sebagai umpan balik yang bermanfaat, tidak hanya bagi dosen, tapi juga bagi mahasiswa.

Responden berinisial DF dengan kategori intelektual tinggi, memaparkan mengenai definisi pendidikan karakter kepada peneliti saat wawancara, seperti berikut :

\footnotetext{
"Pendidikan karakter adalah pendidikan yang mempelajari tentang watak seseorang yang melekat pada dirinya sejak lahir, bisa karena faktor keturunan atau gen, kebiasaan dari dalam lingkungan keluarga, atau pengaruh dari lingkungan masyarakat" (DF, 18)
}

Responden berinisial DF menyatakan bahwa pendidikan karakter bisa diterapkan pada semua mata pelajaran yang ada disekolah, jika siswa memiliki karakter bawaan dari lingkungan keluarga, misal karakter pemalas. Siswa dengan karakter pemalas tidak akan bisa beradaptasi dengan baik dalam proses kegiatan belajar mengajar di kelas. Pembelajaran IPA misalnya, guru membuat sebuah percobaan yang mana siswa-siswi dibagi dalam tim yang bekelompok. Pembelajaran kooperatif atau berkelompok menuntut para siswa-siswi untuk bekerja sama dalam melakukan percobaan, dalam hal ini siswa berkarakter pemalas susah untuk mengikuti alur atau aturan kerja dalam pembelajaran berkelompok. Siswa berkarakter pemalas tidak akan efektif dan efisien dalam mengikuti pembelajaran kooperatif, karena mereka hanya akan mengharapkan hasil langsung tanpa ikut berpartisipasi dalam kegiatan percobaan di mata pelajaran IPA.

Responden DF juga memiliki sedikit pengetahuan tentang penulisan jurnal belajar oleh siswa, dengan singkat responden memaparkan tentang definisi jurnal belajar menurut diri nya sebagai berikut ini

\footnotetext{
"Jurnal belajar adalah proses penulisan atau kegiatan dalam suatu proses belajar mengajar. Saya pernah membuat jurnal belajar ketika berada di SMA. Saya menuliskan kegiatan sehari-sehari saya dalam jurnal tersebut. Penulisan jurnal juga membuat saya lebih mudah dalam mejabarkan kegiatan yang saya lakukan disekolah. Banyak manfaat yang saya dapat penulisan jurnal belajar, saya dapat mengulang kembali pelajaran saat di dalam kelas dalam sebuah penjabaran tulisan" (DF, 18)
} belajar.

Beberapa kendala yang dialami oleh responden DF dalam penulisan jurnal 


\begin{abstract}
"Kendala yang saya hadapi dalam menuliskan jurnal belajar adalah dalam hal memaparkan materi perkuliahan dengan bahasa yang jelas dan singkat, terkadang saya juga biasa mengulang-ulang kembali kalimat yang sudah tuliskan dalam paragraf sebelumnya. Dalam beberapa jurnal juga saya bingung sampaisampai menuliskan isi jurnal berupa ringkasan materi perkuliahan saja" (DF, 18)
\end{abstract}

Salah satu isi jurnal yang di paparkan oleh DF yang benar-benar pas dengan hakiki jurnal belajar sesungguhnya adalah sebagai berikut:

\begin{abstract}
"Pertemuan akhir dalam mata kuliah pendidikan karakter yang bertugas melakukan presentasi adalah HL \& HA, karena HA sedang sakit, jadi HL presentasi sendiri dengan paparan materi 'Memahami para pemikir yang beragam' menurut saya dalam penyampaian materi ini HL tidak begitu menguasai materi nya, itu terbukti dari sesi tanya jawab. Beberapa pertanyaan dari teman-teman dikelas tidak dapat di jawab oleh HL dengan baik dan maksimal, bahkan HL sampai dibantu oleh teman-teman seperti DH, EF, dan NA untuk mnyempurnakan jawaban dari beberapa pertanyaan.” (DF, 18)
\end{abstract}

Hasil belajar responden DH dalam aspek kognitif pada mata kuliah pendidikan karakter, baik nilai UTS dan UAS mendapat presentasi kategori baik, dengan nilai 80. Penuturan responden berikutnya dengan kategori intelektual sedang yang berinisial DH menyatakan bahwa jurnal belajar merupakan hal yang baru bagi responden, karena selama responden menempuh pendidikan di jenjang sebelumnya tidak pernah diminta untuk membuat jurnal belajar. "Selama jenjang pendidikan SD, SMP dan SMA saya tidak pernah diminta untuk
membuat jurnal belajar". (DH, 26)

Berdasarkan wawancara diatas dapat diketahui bahwa pembuatan jurnal belajar ketika mengikuti suatu proses belajar mengajar merupakan hal yang baru bagi responden $\mathrm{DH}$. Sehingga $\mathrm{DH}$ sangat bersemangat diminta untuk membuat jurnal belajar disetiap pertemuannya. Permasalahan yang sering muncul ketika responden DH diminta untuk membuat jurnal belajar berupa kesulitan dalam memilah dan memilih kata dalam pembuatan jurnal belajar.

\begin{abstract}
"Kendala yang saya alami selama penulisan jurnal belajar yaitu saya kesulitan dalam memilih dan memilah kata dalam pembuatan jurnal belajar. Ketika Dosen memaparkan materi didepan kelas, saya dapat menyimak dengan baik apa yang beliau sampaikan, dan apa saja yang kelompok presemtasikan tentang materi tersebut. Akan tetapi kendala terbesar saya adalah ketika saya harus menuangkan apa yang sudah saya dengar itu ke dalam sebuah kalimat. Kesulitan dalam memilih dan memilah kata menjadi masalah terbesar saya dalam pembuatan jurnal ini. Oleh karena itu, mulai sekarang saya harus lebih sering lgi menulis. agar ketika diminta untuk membuat jurnal belajar lagi, saya tidak akan mengalami masalah lagi.” $(\mathrm{DH}, 26)$
\end{abstract}

Responden berinisial DH menyatakan bahwa dalam proses penulisan jurnal belajar mengalami kesulitan dalam memilah dan memilih kata yang akan ditulis dalam jurnal belajar. Kesulitan tersebut diatasi responden dengan usaha lebih rajin lagi dalam menulis.Pendapat responden DH dikutip dari jurnal belajar sebagai berikut: 
"Setelah mengikuti pembelajaran yang diberikan, pada presentasi dilakukan oleh kelompok 1. Yaitu tentang model-model pembelajaran karakter, materi dipaparkan oleh Aulia Rahmi dan Siti Fatimah sudah bisa dipahami dengan baik. Hal ini disebabkan, materi tersebut berkaitan dengan model-model yang berkaitan dengan pembelajaran karakter. Ada 2 model besar dalam program pembelajaran untuk anak sekolah dasar yaitu model pembelajaran kooperatif dan model pembelajaran kognitiif sosial yang mana kedua model ini saling berhubungan satu sama lain. Akhirnya yang dapat saya fahami adalah bahwa setiap individu itu memiliki kemampuan untuk berkembang secara alami apapun lingkungannya." (DH, 26)

Pendapat lain tentang jurnal belajar:

\begin{abstract}
"Setelah mengikuti pembelajaran yang diberikan pada presentasu yang dilakukan oleh Nor Riska tentang pengajaran sebagai pengambilan keputusan. Saya dapat memahami dengan baik materi ini. Karena materi ini sangat berkaitan dengan kehidupan sehari-hari. Dalam materi ini dipaparkan bagaimana mengambil keputusan dan apa saja dasar-dasar dalam mengambil sebuah keputusan. Dasardasar mengambil keputusan adalah intuisis, pengalaman, wewenang, rasional dan fakta. Materi ini saya rasa sangat bermanfaat dalam kehidupan sehari-hari. Dari materi ini saya juga belajar beberapa teori tentang dasar-dasar pengambilan keputusan". (DH, 26)
\end{abstract}

Contoh lain terkait konsep pendidikan karakter. Dikutip dari jurnal belajar responden DH sebagai berikut:

"Pendidikan karakter merupakan proses yang sangat kompleks. Karena karakter itu tidak hanya berhubungan dengan manusia, tapi juga berhubungan dengan Tuhan. Setidaknya ada 5 konsep yang dapat saya fahami tentang pendidikan karakter, yaitu karakter dalam hubungan dengan Tuhan, karakter dalam hubungan diri sendiri, karakter dalam hubungan dengan sesama, karakter dalam hubungan dengan lingkungan, serta karakter yang berhubungan dengan kebangsaan. Ada 2 model besar dalam program pembelajaran untuk anak sekolah dasar yaitu model pembelajaran kooperatif dan model pembelajaran kognitiif sosial yang mana kedua model ini saling berhubungan satu sama lain." (DH, 26)

Konsep pendidikan karakter yang dikutip melalui wawancara pada responden DH sebagai berikut:

“ Pendidikan karakter adalah kegiatan mempelajari karakter anak. Pendidikan karakter sangat penting menurut saya, karena pendidikan karakter bersifat membentuk karakter siswa". (DH, 26)

Hasil wawancara dengan responden DH menunjukkan bahwa jurnal belajar mewakili pemahamannya terhadap materi yang diajarkan. Hasil belajar responden DH dalam aspek kognitif pada mata kuliah pendidikan karakter, baik nilai UTS dan UAS mendapat presentasi kategori cukup baik, dengan nilai 70.Responden lain yang berinisial HA dengan kategori rendah berpendapat bahwa jurnal belajar merupakan sarana menuangkan pemahaman dia pada jurnal belajar yang ditulis setelah proses pembelajaran berlangsung

Permasalahan yang sering muncul ketika responden HA diminta untuk membuat jurnal belajar berupa kesulitan dalam menuliskan materi yang didapat ketika proses pembelajaran berlangsung. Hal ini tercermin melalui tuturan responden kepada peneliti saat wawancara, sebagai berikut: 


\begin{abstract}
"Kendala yang saya alami selama penulisan jurnal belajar yaitu saya kurang memahami materi yang diajarkan dan kesulitan dalam menyusun kalimat. Ketika bu Dian memaparkan materi didepan kelas, saya sering tidak memperhatikan sehingga materi sering terlewatkan atau tidak saya perhatikan. Sebagai dampaknya, saya tidak memahami materi tersebut dengan baik. selain itu, saya kesulitan dalam mengarang di jurnal belajar. Hal ini disebabkan saya suliat dalam membuat kalimat." (HA, 18)
\end{abstract}

Responden berinisial HA menyatakan bahwa dalam proses penulisan jurnal belajar mengalami kesulitan dalam memaparkan perihal materi yang telah dia pahami. Kesulitan tersebut disebabkan dia tidak memperhatikan penjelasan dari dosen. Pendapat responden HA dikutip dari jurnal belajar sebagai berikut:

\begin{abstract}
"Setelah mengikuti pembelajaran yang ibu berikan, pada presentasi dilakukan oleh kelompok 10. Materi dipaparkan sudah bisa dipahami dengan mudah. Hal ini sebabkan, materi tersebut berkaitan dengan kecerdasan. Kecerdasan adalah kemampuan untuk memecahkan masalah. Kecerdasan melibatkan penggunaan pengetahuan dan keterampilan.” (HA, 18)
\end{abstract}

Contoh lain terkait konsep pendidikan karatker. Dikutip dari jurnal belajar responden HA sebagai berikut:

"Pendidikan karakter merupakan proses sangat panjang, karena pendidikan karakter bukan proses transfer ilmu pengetahuan melainkan penanaman nilai. Proses penanaman nilai dalam dilakukan melalui model pembelajaran kognitif sosial. Penggunaan model kognitif sosial bertujuan meningkatkan keterampilan sosial dan efektif membelajarkan siswa dalam berbagai konteks sosial." (HA, 18)

Hasil kutipan dari jurnal belajar menunjukkan responden HA memang memahami konsep pendidikan karakter dan salah satu metode yang digunakan dalam menanamkan nilai-nilai karakter pada siswa. konsep pendidikan karakter yang dikutip melalui wawancara pada responden HA sebagai berikut:

"Pendidikan karakter adalah pengetahuan tentang sifat-sifat setiap individu. Karakter yang dimaksud adalah karakter dalam ruang lingkup anak sekolah dasar." (HA, 18)

Hasil belajar responden HA dalam aspek kognitif pada mata kuliah pendidikan karakter, baik nilai UTS dan UAS mendapat presentasi kategori tidak baik, dengan nilai 50 .

\title{
KAJIAN
}

Berdasarkan paparan terkait pemanfaatan jurnal belajar bagi mahasiswa yang menjadi responden penelitian di STKIP PGRI Banjarmasin. jurnal belajar dimanfaatkan sebagai alat bantu untuk mengetahui persepsi mahasiswa terkait materi yang telah diajarkan. Persepsi tersebut bermacam-macam tergantung pendapat dari responden tersebut. Pada dasarnya jurnal belajar memaparkan pemahaman responden terhadap materi yang masih membekas dalam ingatannya. Selain itu, jurnal belajar dapat digunakan untuk mengamati perkembangan 
kemampuan responden dalam menangkap materi yang diajarkan. Hasil belajar yang terlaksana pada setiap pertemuan dapat dilihat oleh dosen pengampu mata kuliah.

Pembuatan jurnal belajar memiliki kendala yang cukup berarti bagi responden. Kendala tersebut berasal dari diri responden. Kendala dapat diminimalkan melalui latihan menulis jurnal belajar. Bimbingan dosen pengampu mata kuliah sangat berarti demi selesainya penulisan jurnal belajar yang mewakili proses pembelajaran yang telah berlangsung. Melalui bimbingan dalam penulisan jurnal belajar, diharapkan akan memperbaiki kemampuan responden dalam menulis jurnal belajar sehingga akan berdampak meningkatnya kemampuan dalam menulis jurnal.

\section{PENUTUP \\ KESIMPULAN DAN SARAN \\ Kesimpulan}

Jurnal belajar dapat digunakan untuk mengamati perkembangan kemampuan responden dalam menangkap materi yang diajarkan. Hasil belajar yang terlaksana pada setiap pertemuan dapat dilihat oleh dosen pengampu mata kuliah.

\section{Saran}

Kendala dapat diminimalkan melalui latihan menulis jurnal belajar. Bimbingan dosen pengampu mata kuliah sangat berarti demi selesainya penulisan jurnal belajar yang mewakili proses pembelajaran yang telah berlangsung. Melalui bimbingan dalam penulisan jurnal belajar, diharapkan akan memperbaiki kemampuan responden dalam menulis jurnal belajar sehingga akan berdampak meningkatnya kemampuan dalam menulis jurnal.

\section{DAFTAR RUJUKAN}

Burns, H.D. 1999. Collaborative Action Research for English Language Teachers.

Cambridge : Cambridge University Press.

Creighton, T. (2009). Character Education : An Hystorical Review. The International Journal of Educational Leadership Preparation, Volume 4, Number 1 (January - March, 2009Dahlan MD. (1990) Model-model Mengajar, Bandung; Diponogoro.19

David Elkind \& Freddy Sweet. 2004. Caracter Education. New York : Oxford

DIRJEN DIKTI. 2010. Kerangka Acuan Pendidikan Karakter. Jakarta

Melinda,CB., Berkowitz MW. (2005). What Work in Character Education? Leadership For Students Activities, October 2005, vol 34, no 2, page 1-7

Mulyasa.2003. Kurikulum Berbasis Kompetensi. Konsep; Karakteristik dan Implementasi.

Schwartz, AJ. (2000). It's Not to Late to Teach College Student about Values. The Chronicle of Higher Education. Vol 46. No 40.pg A68 
Siswanto, HW. (2011). Pendidikan Karakter: Apa, Mengapa, dan Bagaimana Implementasinya di Satuan Pendidikan. Pusat Kurikulum dan Perbukuan, Balitbang Kemendiknas.

Syukri. (2009). Peran Pendidikan di Perguruan Tinggi terhadap Perubahan Perilaku Kaum Intelektual (sosial-Individu). Jurnal Ilmiah Kreatif.vol 6 no 1, hal 1-15.

Stiff-William, HR. (2010). Widening Lens toTeach Character Education Zuchdi, dkk, 2009, Pendidikan Karakter. Jogjakarta:UNY Press. 